\title{
Endocranium and ecology of Eurotherium theriodis, a European hyaenodont mammal from the Lutetian
}

\author{
Morgane Dubied, Floreal Solé, and Bastien Mennecart \\ Acta Palaeontologica Polonica 66 (3), 2021: 545-554 doi:https://doi.org/10.4202/app.00771.2020
}

Hyaenodonts are extinct placental mammals with a carnivorous diet. Their phylogenetic position among mammals and the relationships within Hyaenodonta are at present partially unresolved. The endocranium is a structure that has rarely been studied in this clade. Using 3D tomography, we studied the endocranium of the European hyaenodont Eurotherium theriodis , discovered in Egerkingen (Switzerland, Lutetian, middle Eocene). Eurotherium theriodis has an endocranium morphology that supports an increase in size of the cerebrum relative to the cerebellum over time within the Hyaenodontoidea. The endocranium also supports a complexification of the cerebrum (i.e., at least two furrows per cerebral hemisphere) within the Hyaenodontoidea and allows us to envisage an increase of the encephalization quotient (EQ), over time. Based on morphology, we consider that its endocranium does not depart from that of the hyaenodontoids known in the Lutetian, Bartonian, and Priabonian of Europe, being less complex than that of the hypercarnivorous Hyaenodon. However, the morphology of its olfactory bulbs and turbinates is similar to that observed in Hyaenodon. The large size of the turbinates of $E$. theriodis is regarded to be the result of a possible scavenger ecology and agrees with the meat/bone diet envisaged based on the analysis of the morphology of the skull and teeth.

Key words: Mammalia, Hyaenodonta, endocranium, phylogeny, ecology, olfaction, Eocene.

Morgane Dubied [morgane.dubied@u-bourgogne.fr], Biogeosciences, UMR 6282 CNRS, EPHE, Université Bourgogne Franche-Comté, 6 bd Gabriel, 21000 Dijon, France. Floreal Solé [floreal.sole@ naturalsciences.be ] (corresponding author), D.O. Earth and History of Life, Royal Belgian Institute of Natural Sciences, Rue Vautier 29, B-1000 Brussels, Belgium. Bastien Mennecart [mennecartbastien@gmail.com], Natural History Museum Basel, Augustinergasse 2, 4001 Basel, Switzerland; Natural History Museum Vienna, Burgring 7, 1010 Vienna, Austria. 
This is an open-access article distributed under the terms of the Creative Commons

Attribution License (for details please see creativecommons.org), which permits unrestricted use, distribution, and reproduction in any medium, provided the original author and source are credited.

FoF Full text $(1,025.0 \mathrm{kB})$ 